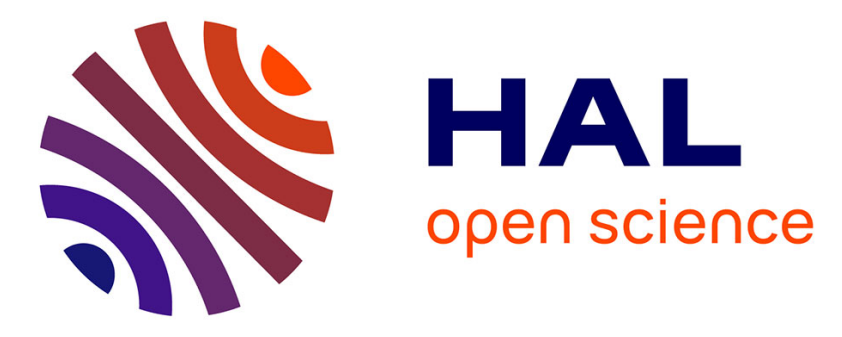

\title{
Evolution and Vitality of Seagrasses in a Mediterranean Lagoon
}

\author{
Lila Ferrat, Vanina Pasqualini, Catherine Fernandez, Christine \\ Pergent-Martini, Gérard Pergent
}

\section{To cite this version:}

Lila Ferrat, Vanina Pasqualini, Catherine Fernandez, Christine Pergent-Martini, Gérard Pergent. Evolution and Vitality of Seagrasses in a Mediterranean Lagoon. Journal of Environmental Science and Health, Part A, 2003, 38 (8), pp.1459-1468. 10.1081/ESE-120021470 . hal-01768924

\section{HAL Id: hal-01768924 \\ https://hal.science/hal-01768924}

Submitted on 17 Apr 2018

HAL is a multi-disciplinary open access archive for the deposit and dissemination of scientific research documents, whether they are published or not. The documents may come from teaching and research institutions in France or abroad, or from public or private research centers.
L'archive ouverte pluridisciplinaire HAL, est destinée au dépôt et à la diffusion de documents scientifiques de niveau recherche, publiés ou non, émanant des établissements d'enseignement et de recherche français ou étrangers, des laboratoires publics ou privés. 


\title{
Evolution and Vitality of Seagrasses in a Mediterranean Lagoon
}

\author{
Lila Ferrat, ${ }^{*}$ C. Fernandez, V. Pasqualini, G. Pergent, \\ and C. Pergent-Martini \\ Equipe Ecosystèmes Littoraux Université de Corse, \\ Faculté de Sciences et Techniques, Corte, France
}

\begin{abstract}
Despite their registration on the list of the Ramsar convention sites, the Mediterranean lagoons rarely beneficiate of an effective protection, and are particularly sensitive to environmental quality. A control of these wetlands needs the creation of an inventory of knowledge for the concerned environment. In this perspective, the seagrass beds were followed up in the coastal lagoon of Urbino (Corse, France) since 1990. A cartographic study was carried out by remote sensing of aerial photography. Temporal evolution of the seagrass beds (Cymodocea nodosa principally) allows to determine the vitality of these structures. A comparison of the surface areas occupied by Cymodocea nodosa, between 1990 and 1999, did not allow seeing any significant evolution. However, some variations appear like biotopes all more fragile and coveted as the Mediterranean coastal fringe is straight and is the privileged site of appear in the localization of the beds, due to the modification of environmental conditions in the lagoon.
\end{abstract}

Key Words: Wetlands; Lagoon; Remote sensing; Seagrass bed.

*Correspondence: Lila Ferrat, Equipe Ecosystèmes Littoraux Université de Corse, Faculté de Sciences et Techniques, B.P. 52, 20250 Corte, France; E-mail: ferrat@univ-corse.fr. 


\section{INTRODUCTION}

The aim of this study was to establish a cartography of aquatic phanerogams present in a Corsican littoral lagoon. Indeed, the importance of these wetlands for the future of the planet is more and more evident. Whatever the topology of these wetlands (e.g., marsh, coastal lagoons, salt marsh, deltas), these mediums are characterized by exceptional productivity and biological diversity. Furthermore, they constitute an important income supply for the local biocenosis. ${ }^{[1]}$ That way, in a general manner, Mediterranean coastal lagoons show very high primary and secondary productions, that yield their use favorable to fishing and aquaculture. $^{[2]}$

Wetlands appear like biotopes all more fragile and coveted, that the Mediterranean coast is straight and is the privileged site of many economic activities, and of an increasing urbanization. That way, about one million hectares of wetlands have been destroyed since 50 years. ${ }^{[3]}$ Despite their registration on the list of the Ramsar convention sites, the Mediterranean lagoons rarely beneficiate of an effective protection, and are particularly sensitive to environmental quality. Indeed, wetlands have often been considered like insalubrious zones that must dried, and have been dealt with in treatments by pesticides that could affect the quality of these environments. ${ }^{[4]}$

Actually, a management of these zones goes through the creation of a state of knowledge concerning the environment to manage. ${ }^{[5]}$ Indeed, there is actually too few data to help the organisms responsible for the monitoring of these environments. It seems that some approaches would be essential for the protection of the coastal zone. It is fitting to dispose, in a first time, of information on present resources (faunistic and floristic inventories) and on their localization (cartographies).

The aim of this study is to characterize the biocenosis and the different bottom types of a Corsican lagoon with (i) the realization of cartographies by remote sensing, (ii) the comparison of the repartition of biocenosis to pre-existing data, and (iii) the evaluation of the vitality of seagrass beds, taking into account parameters inherent in the plant (e.g., biomass and density).

\section{MATERIAL AND METHODS}

\section{Site}

The Urbino lagoon is located in the fringe of the Corsican oriental plain, below Aleria (Fig. 1). With a circular form, it covers an area of 760 ha. The lagoon is separated in two parts by an important Western peninsula: Isula Lunga, and possesses a South-western island. The North-eastern and Eastern shores are flatbottomed, sandy, whereas the island, both sides and North-western shores of the peninsula present little cliffs. The communication with the sea is made by a natural channel, situated at the North. The inputs of freshwater occur preferentially in the North-western part of the lagoon, by little streams and by running rainwater. All around the lagoon, "pozzi" or temporary swamps and mud-marsh, collect the waters of the catchment basin before their reject in the lagoon. 

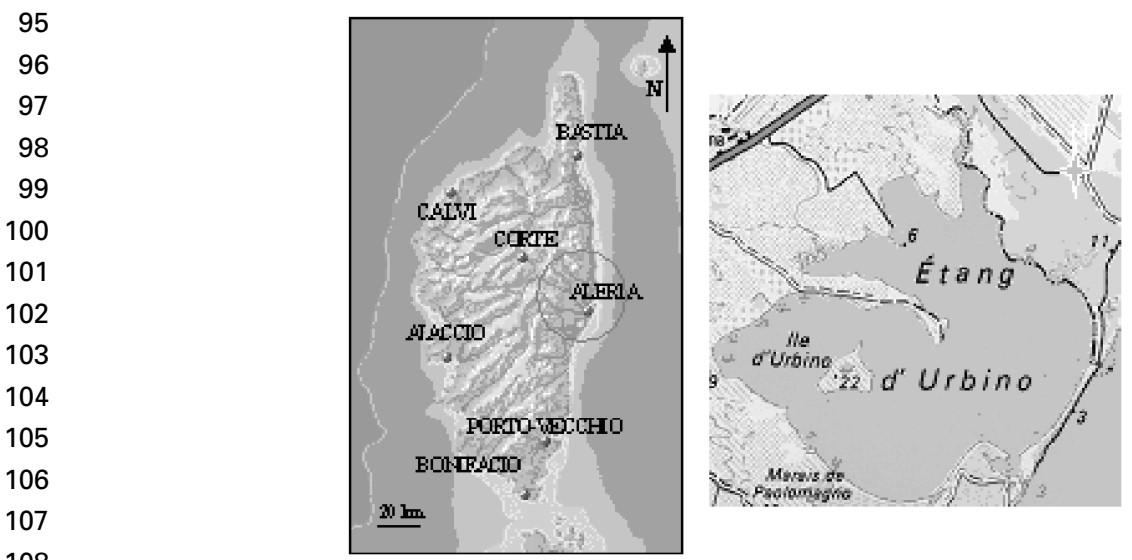

Figure 1. Localization of the Urbino lagoon.

\section{Cartography of Biocenosis and Bottom Types}

Five aerial photographs $(1 / 10,000)$ were realized in June 1999 (Compagnia Generale Ripresaeree di Parma ${ }^{\circledR}$ ). The photographs were digitized by means of a color scanner (UMAX Mirage II, driven by a Pentium II MMX $350 \mathrm{Mg} \mathrm{Hz}$ microcomputer), in 16.8 million colors, with a resolution of $127 \mathrm{dpi}$. Each photograph pixel $(2 \mathrm{~m})$ corresponds to a vector of properties, formed of reflectance for each base color in the visible spectrum: red, green, and blue (R, G, B).

Pre-processing and processing of data were realized using the Multiscope software (version 2.4 and 3.01, Matra Cap System ${ }^{\circledR} .{ }^{[6]}$ Pre-processing involved specific geometrical rectification in order to eliminate distortions in the photographs. Reference points were taken from the terrestrial parts of the photograph. The terrestrial domain was eliminated on the raw image by delimiting the land-sea boundary. The dynamics were adjusted by enhancing the contrast of the image (linear contrast enhancement) thus improving precision and clarity. The remote sensing carried out on the aerial photograph involved exploiting the maximum amount of data.

A Principal Component Analysis (PCA) was applied to the green and blue planes. A classification supervised by generalized hypercube was applied to the colored composition, and involved positioning polygons assumed to contain pixels belonging to the same assemblage and bottom type. The positioning of the polygons was therefore based on in situ field observations. Identification of benthic assemblages was carried out by SCUBA diving in June 1999 for aerial photography. Positioning was realized by means of GPS (Global Positioning System: Valsat MLR). The degree of reliability of the cartography was evaluated with a scale of reliability. ${ }^{[6]}$

\section{Biomass and Density}

Samplings were realized with a $15 \mathrm{~cm}$ diameter $/ 50 \mathrm{~cm}$ high cylindrical thief. A 


\begin{abstract}
142 corresponds to the number of shoots per $\mathrm{m}^{2}$. Shoots were numbered in the 143 laboratory. Values are given per $\mathrm{m}^{2}$. The biomass was measured in endogenous 144 tissues (rhizomes and roots) and epigenous tissues (foliar shoots). Each fraction was 145 put in a drying oven $\left(60^{\circ} \mathrm{C}\right)$ up to the obtaining of a constant weight $(48 \mathrm{~h})$.

\section{RESULTS AND DISCUSSION}

\section{Species}

The field observations allowed to identify different species of phanerogams, with species from Ruppiaceae (the differentiation between Ruppia cirrhosa and Ruppia maritima could not be realized), Zosteraceae (Zostera noltii) or Cymodoceaceae (Cymodocea nodosa). Ruppia sp. is present under monospecific beds, near the stream outlets. Zostera noltii, a species particularly linked to poikilohaline environments, is present, in the Urbino lagoon, under monospecific beds of very small dimension, in very localized sectors (near the channel). Cymodocea nodosa is the best represented species of this lagoon. It is encountered generally in sheltered sites of the open sea, but also in coastal lagoons when the salinity is adequate (e.g., Diane and Urbino lagoons in Corsica, Sardinia lagoons). The Cymodocea nodosa beds are present all over the periphery of the lagoon, under monospecific or mixed beds, in association with Zostera noltii or Ruppia sp.
\end{abstract}

\title{
Cartography of Biocenosis
}

With the remote sensing, four biocenosis or bottom types were identified: soft sands, pebbles, coarse shell sand, beds of phanerogams, mud (Fig. 2).

The total surface of the lagoon is about 710 ha, with the exclusion of swampy zones. Soft sands are essentially represented on the periphery of the lagoon. They occupy 57.6 ha, or $8.1 \%$ of the total surface (Table 1). Pebbles and coarse shell sands are localized on very small surfaces. They only represent $1.1 \%$ of the global surface and are essentially present in the Northern part (Table 1). The mud is the main bottom type of the lagoon, with surfaces higher than $70.1 \%$ (Table 1). It occupies the quasi totality of the central part. Phanerogam beds form a quasi-discontinuous belt on the periphery of the lagoon that can reach $300 \mathrm{~m}$. They are generally present in the superficial bathymetric portion (between the surface and $4 \mathrm{~m}$ depth), representing superficies of $147 \mathrm{ha}$, that is to say $20.7 \%$ of the lagoon (Table 1 ).

\section{Cartographic Reliability}

The application of a reliability scale to the cartography of the Urbino lagoon provides a value of $87.8 \%$ (Table 2 ). 


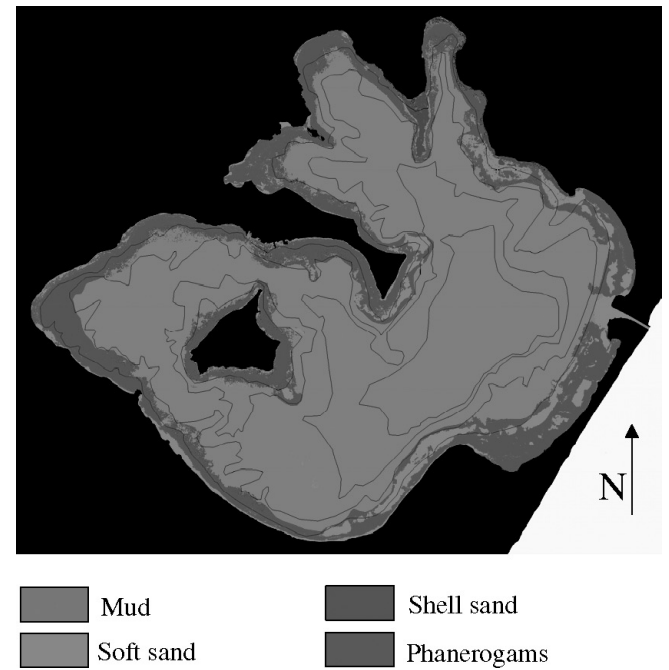

Figure 2. Localization of biocenosis and bottom types in the Urbino lagoon in 1999.

Table 1. Surfaces occupied by the biocenosis and bottom types in the Urbino lagoon in 1999.

\begin{tabular}{lcr}
\hline Themes & Surfaces (ha) & $\%$ \\
\hline Mud & 497.2 & 70.10 \\
Pebbles and coarse & & \\
$\quad$ shell sand & 7.9 & 1.10 \\
Soft sand & 57.6 & 8.10 \\
Phanerogams & 147.0 & 20.70 \\
Total & 709.7 & 100.00 \\
\hline
\end{tabular}

\section{Evolution of the Beds of Phanerogams}

The Urbino lagoon was before subjected to cartographic studies. ${ }^{[4,7,8]}$ All of them come from in situ identifications, followed by an empiric extrapolation. But, since 1990, several studies have been carried out using remote sensing on aerial photography, and notably in 1990 (unpublished data), 1994, ${ }^{[6]}$ and 1996. ${ }^{[9]}$ These data constitute a reliable support for a temporal monitoring of the evolution of biocenosis and bottom types (Fig. 3).

By comparison of percentages of the whole biocenosis and bottom types, between 1990 and 1999, no significant difference can be noted. But variations appear in the localization of the beds of phanerogams, showing, in 1999, a greater extension at the peninsula and a regression in the Northern and the Western parts of the lagoon.

An important regression of soft sand surfaces and beds is noted in 1994, on behalf of the mud. These fluctuations could be linked to exceptional precipitations in 
Table 2. Estimation of the cartographic reliability of the Urbino lagoon.

\begin{tabular}{lc}
\hline Factors & Urbino lagoon \\
\hline Site & Weak and irregular $=2$ \\
Topography: slope & 0 to $5 \mathrm{~m}=3$ \\
Bathymetric section & $75 \%$ of the bathymetric \\
Turbidity: visualization of & section $=2$ \\
$\quad$ biocenosis and bottom types & Different $=2$ \\
Nature of biocenosis and & \\
$\quad$ bottom types & \\
Photographies & Very good $=3$ \\
Quality & Surface effect far \\
Surface effect: specular reflection, & from the site $=2$ \\
$\quad$ wave effect & Pixel $=2 \mathrm{~m}=3$ \\
Numerisation & Number $>20=3$ \\
Pixel size & In the four directions $=3$ \\
Geometric correction & Referential $<$ image $=1$ \\
Landmarks & \\
$\quad$ number: distribution & $10 \%$ Surface $>5 \%$ of the \\
Scale of referential/scale of image & surface of study $=2$ \\
Field data & \\
Surface covered by the field & $30>$ Number $>15=2$ \\
$\quad$ date/surface of study & \\
Classification & \\
Number of polygons by & \\
biocenosis or bottom types & $87.8 \%$ \\
Total & \\
Percentage of reliability & \\
\hline
\end{tabular}

November 1993. Indeed, about $14 \times 10^{6} \mathrm{~m}^{3}$ of freshwater, corresponding to $36 \%$ of the total volume of the lagoon $\left(38.5 \times 10^{6} \mathrm{~m}^{3}\right)$ have been poured. This water, rich in suspended matters, could be the cause for the increase of mud surfaces noted in June 1994.

In 1996 (Fig. 3), an important increase of the beds at the expense of sands (soft and coarse shell sand) and pebbles. This overestimation of the beds could be due to (i) the fact that swamps have been taken into account, contrary to the other years, (ii) a confusion between pebbles, coarse shell sands, and beds, due to the partial colonization of these substrates by photophilous algae, having a spectral response near those of phanerogams.

\section{Characterization of Cymodocea nodosa Beds}

The mean density of beds is of $1490+518$ shoots per $\mathrm{m}^{2}$ (IC of $95 \%$ ). This density is similar to those usually reported in the literature (Table 3).

The mean total biomass is $767.3 \pm 176.8 \mathrm{~g} \mathrm{dw} \mathrm{m}^{-2}$. The greater part of this biomass is represented by the endogenous biomass $\left(611.6 \pm 173.3 \mathrm{~g} \mathrm{dw} \mathrm{m}^{-2}\right.$ in mean). The 


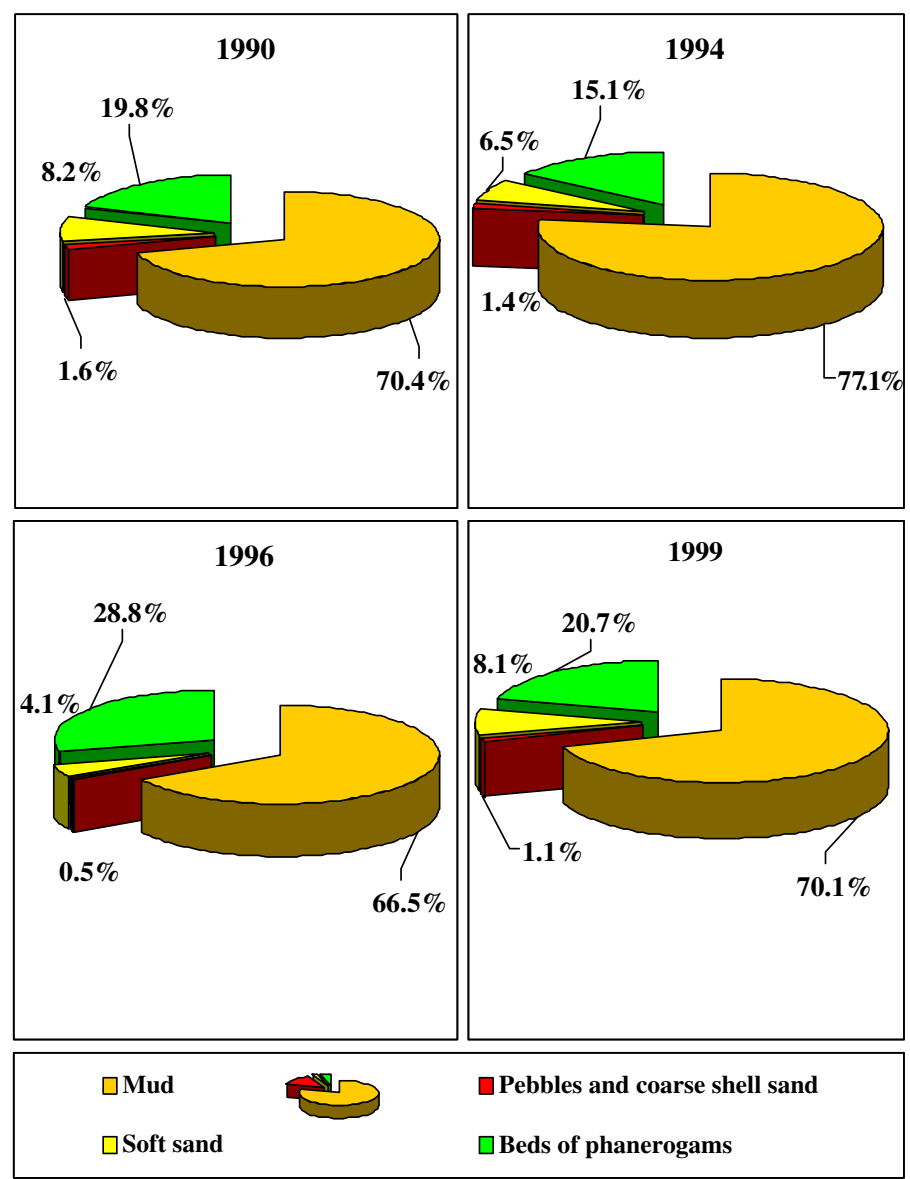

Figure 3. Different surfaces occupied by the biocenosis and bottom types in the Urbino lagoon in 1990 (unpublished data), 1994, ${ }^{[6]} 1996,{ }^{[9]}$ and 1999 (this study).

epigenous biomass presents lower values $\left(156.3 \pm 49.5 \mathrm{~g} \mathrm{dw} \mathrm{m}^{-2}\right.$ in mean). These values are similar to those observed in other Mediterranean lagoons. ${ }^{[20]}$ If we consider that the beds are for $99 \%$ of Cymodocea nodosa, the biomass represents 1128 tons dw.

Beyond the aquatic phanerogams, several species of macrophytes have been identified in the lagoon (Table 4), and colonize the quasi-totality of the substrates. This algal biomass is very variable (Table 4) and is, in mean of $603.2 \pm 577.3 \mathrm{~g} \mathrm{dw} \mathrm{m}^{-2}$. This value is similar to the one of Cymodocea nodosa. Moreover, some species present very elevated biomass. It is notably the case for the rhodophyte Gracilaria dura. Gracilaria have been signalled in the lagoon. ${ }^{[4,7]}$ These rhodophyceae develop preferentially when environmental conditions are not favorable to phanerogams, that is to say when the grain size distribution of sediment and light decrease. ${ }^{[2]}$ These biocenosis are important in term of primary production and must be taken into account to assess the functioning of lagoon mediums.

\section{AQ1}




\begin{tabular}{|c|c|c|c|c|}
\hline \multirow{2}{*}{$\begin{array}{l}330 \\
331 \\
332 \\
332\end{array}$} & \multicolumn{4}{|c|}{$\begin{array}{l}\text { Table 3. Variations of Cymodocea nodosa density according to the site } \\
\text { ( } \mathrm{Nb} \text { shoots/M, maximal and minimal values). }\end{array}$} \\
\hline & Site & Prof. & Density & References \\
\hline 334 & Ischia-Italy & $4.0 \mathrm{~m}$ & 88-196 & {$[10]$} \\
\hline 335 & Arguin-Mauritania & $1.0 \mathrm{~m}$ & $192-577$ & {$[11]$} \\
\hline 336 & Antibes-France & $2.0 \mathrm{~m}$ & $1,647-2,067$ & {$[12]$} \\
\hline 337 & Diane lagoon-France & $0.5-5.3 \mathrm{~m}$ & $533-1,955$ & [13] \\
\hline 338 & Ischia-Italia & $4.0 \mathrm{~m}$ & $380-1,160$ & [14] \\
\hline $\begin{array}{l}300 \\
339\end{array}$ & Mar Menor-Spain & $0.5 \mathrm{~m}$ & $312-2,314$ & {$[15]$} \\
\hline 339 & Ischia-Italy & $4.0 \mathrm{~m}$ & $188-1,925$ & {$[16]$} \\
\hline 340 & Ebre-Spain & $3.0 \mathrm{~m}$ & $1,000-2,000$ & {$[17]$} \\
\hline 341 & Canaries-Spain & $6.0 \mathrm{~m}$ & 934-1,928 & {$[18]$} \\
\hline 342 & Venice lagoon-Italia & $1.0 \mathrm{~m}$ & $860-2,302$ & [19] \\
\hline 343 & Venice lagoon-Italia & $0.6 \mathrm{~m}$ & $1,650-3,377$ & [20] \\
\hline
\end{tabular}

345

346

347

348

349

350

351

352

353

354

355

356

357

358

359

360

361

362

363

364

365

366

367

368

369

370

371

372

373

374

375

376

Table 4. Different algal biomass $\left(\mathrm{g} \mathrm{dw} \mathrm{m}^{-2}\right)$ in the Urbino lagoon.

\begin{tabular}{lllr}
\hline No of sample & \multicolumn{1}{c}{ Species } & \multicolumn{1}{c}{ Type } & Biomass $(\mathrm{g} / \mathrm{m})$ \\
\hline 1.2 & Gracilaria dura & Rhodophyceae & 252.50 \\
1.2 & Dictyota linearis & Chromophyceae & $1,537.50$ \\
1.3 & Lophosiphonia subadunca & Rhodophyceae & 11.87 \\
1.3 & Gracilaria dura & Rhodophyceae & $3,123.94$ \\
1.5 & Gracilaria dura & Rhodophyceae & 168.57 \\
1.5 & Alsidium corallinum & Rhodophyceae & 68.09 \\
2.2 & Polysiphonia elongata & Rhodophyceae & $1,892.50$ \\
4.1 & Cladophora & Chlorophyceae & 2.13 \\
4.1 & Gracilaria bursa-pastoris & Rhodophyceae & 5.82 \\
4.2 & Polysiphonia elongata & Rhodophyceae & 110.00 \\
4.4 & Polysiphonia elongata & Rhodophyceae & 2.61 \\
\hline
\end{tabular}

\section{CONCLUSIONS}

In this study, we have established cartographies of the repartition of the principal biocenosis (essentially aquatic phanerogams) and of the bottom types of the Urbino lagoon. Thanks to the actual techniques of remote sensing, applied to the aerial teledetection, we have identified and localized with precision $(2 \mathrm{~m}$ pixel $)$ the phanerogam beds.

At least three species of aquatic phanerogams have been observed Cymodocea nodosa, Zostera noltii, and Ruppia sp. These species form generally monospecific beds (dominant in term of occupied surfaces) and plurispecific formations in a less extend. In a general manner, the aquatic phanerogam beds are well represented in this lagoon (20.7\% of the total surface), with a predominance of Cymodocea nodosa beds, but in term of biomass, alga can be more important than phanerogam. 
The beds seem to follow temporal fluctuations every year, notably in term of repartition, indeed, a comparison of the surface areas occupied by Cymodocea nodosa (150 ha), between 1990 and 1999, did not allow to see any significant evolution. However, some variations appear in the localization of the beds, due to the modification of environmental conditions in the lagoon.

This study confirms the important vitality of beds in this Corsican lagoon and this could explain its high productivity. ${ }^{[22]}$

However, signs of mudding must be actively observed. Indeed, by their improbable effect on phanerogams, their origin must be determined in order to verify if it corresponds to punctual and reversible meteorological phenomenon such as those registered in 1994, or if they correspond to a dynamic of lagoon overloading.

The remote sensing technique, carried out in this study, confirms the potentialities of this tool in the framework of the monitorage of lagoon ecosystems. Indeed, it allows considering a global and precise monitoring of the macrophyte formations of these environments, and could be extended to other Mediterranean coastal lagoons.

\section{REFERENCES}

1. Pearce, F.; Crivelli, A.J. Caractéristiques Générales des Zones Humides Méditerranéennes. Conservation des Zones Humides Méditerranéennes; Programme MedWet, Fondation Tour du Valat publish.: Arles, 1994; 89 pp.

2. Deslous-Paoli, J.M. Proposition de Programme 1997-2000. Programme P.N.O.C.II, Atelier: Lagunes Méditerranéennes, IFREMER, 1997; 52 pp.

3. Ramade, F. La conservation des écosystèmes littoraux Méditerranéens. Bull. Soc. Zool. France 1990, 114 (3), 121-136.

4. SOMIVAC, CTGREF. Etude des écosystèmes des étangs de Biguglia, Diana et Urbino. Rapp. SOMIVAC \& CTGREF/Mission Interministérielle pour la Protection et l'Aménagement de l'Espace Naturel Méditerranéen, 1979, $1-59+$ annexes.

5. Pergent-Martini, C.; Pergent, G. Are marine phanerogams a valuable tool in the evaluation of marine trace-metal contamination: example of the Mediterranean sea. Int. J. Environ. Poll. 2000, 13 (1-6), 126-147.

6. Pasqualini, V.; Pergent-Martini, C.; Fernandez, C.; Pergent, G. The use of airborne remote sensing for benthic cartography: advantages and reliability. Int. J. Remote Sensing 1997, 18 (5), 1167-1177.

7. Casabianca, M.L. De; Kiener, A.; Huve, H. Biotopes et biocénoses des étangs saumâtres corses: Biguglia, Diana, Urbino, Palo. Vie Milieu 1972-1973, 23 (2C), $187-227$.

8. Coeurdacier, P. Rapport d'activité sur les étangs de Diana et d'Urbino. IFREMER Santa Maria di Poggio 1987, 14-24.

9. Agostini, S.; Pergent, G.; Capiomont, A.; Pergent-Martini, C. Les étangs de Corse, Etat de référence 1997. Contrat Equipe Ecosystèmes LittorauxUniversité de Corse/Office de l'Environnement de la Corse \& IFREMER 1997; 34 pp. 
10. Mazzella, L.; Scipione, M.B.; Buia, M.C.; Russo, G.F. In situ measurements and sampling techniques on Cymodocea nodosa (Ucria) Ascherson prairies. Rapp. Commiss. Int. Explor. Sci. Médit. 1986, 30 (2), 265.

11. Pergent, G.; Pergent, C.; Vuignier, G. Données préliminaires sur les herbiers de phanérogames marines du banc d'Arguin (Mauritanie). GIS Posidonie Publ. 1988, $1-55$.

12. Caye, G.; Meinesz, A. Observations of the vegetative development, flowering and seeding of Cymodocea nodosa (Ucria) Ascherson on the Mediterraean coast of France. Aquatic Botany 1985, 22, 277-289.

13. Goubin, C. Les phanérogames marines de l'étang de Diana (Haute Corse) étude cartographique et biologique. DEA "Environnement marin," Univ. Aix-Marseille II, 1990, 26 pp. + Ann.

14. Mazzella, L. Il ruolo dei sistemi a fanerogame marine nell'economia delle communità costiere ed i problemi causati dal distrubo antropico. In Inquinamento ed ecosistemi acquatici; Dumontet, Landi, E., Eds.; Atti Congresso Ordine Nazionale dei Biologi, 1990, 103-116.

15. Terrados, J.; Ros, J.D. Growth and primary production of Cymodocea nodosa (Ucria) Ascherson in a Mediterranean coastal lagoon: the Mar Menor (SE Spain). Aquatic Botany 1992, 43, 63-74.

16. Mazzella, L.; Gambi, M.C.; Scipione, M.B.; Buia, M.C.; Lorenti, M.; Zupo, V.; Russo, G.F.; Cancemi, G.; Procaccini, G. An Overview on Functioning Mechanisms of the Posidonia Ecosystem in the Mediterranean Sea. In International workshop on seagrass biology; Kominato, Aug 24-26, 1993.

17. Perez, M.; Romero, J. Growth dynamics, production, and nutrient status of the seagrass Cymodocea nodosa in a Mediterranean semi-estuarine Environment. Mar. Ecol. PSZNI 1994, 15 (1), 51-64.

18. Reyes, J.; Sanson, M.; Afonso-Carillo, J. Leaf phenology, growth and production of the seagrass Cymodocea nodosa at El Medano (south of Tenerife, Canary Islands). Bot. Mar. 1995, 38, 457-465.

19. Rismondo, A.; Curiel, D.; Marzocchi, M.; Scattolin, M. Seasonal pattern of Cymodocea nodosa biomass and production in the lagoon of Venice. Aquatic Botany 1997, 58 (1), 55-64.

20. Sfriso, A.; Ghetti, P.F. Seasonnal variation in biomass, morphometric parameters and production of seagrasses in the lagoon of Venice. Aquatic Botany 1998, 61, 1-17. 